\title{
The Managerial Roles of Academic Library Directors: The Mintzberg Model
}

\author{
Michael Ann Moskowitz
}

This study examines the internal and external managerial roles of academic library directors based on a model developed by Henry Mintzberg. External managerial roles involve the director with commitments and activities outside the library; internal managerial roles focus on staffing and planning issues within the library. The work contacts of academic library directors were studied as a follow-up to the analysis of managerial roles. Although much has been written recently on the manager's need to cultivate external organizational ties, survey results indicated that the ninety-seven responding directors were primarily involved with internal managerial roles and work contacts.

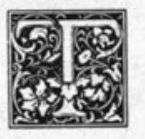

he academic library is part of a larger institution whose curriculum, philosophy, politics, and fiscal status have major implications for the way the library operates. The academic library director must not only be concerned with the internal activities of the library, but be actively involved in the academic institution where the actual requirements of library services are set.

In the mid 1970s, Susan Lee and Paul Metz investigated the internal and external work orientations of academic library directors. Based on interviews with twenty directors in northeastern colleges and universities, Lee found that respondents devoted much of their time to dealing with academic administration and other groups outside the library. ${ }^{1}$ In response to a question on the frequency of work-related contacts beyond the library, 15 percent of the directors answered "nearly all the time" and 60 percent answered "rather often." Her study indicated that directors experienced conflict between their various external activities as "ambassador" for the library and their internal roles as library manager. On the one hand, they were dependent on good relations with administrators to insure adequate support for the library; on the other, they felt countervailing pressures from their subordinates to be more involved on a day-to-day basis with the library staff.

Using a national sample of 266 academic institutions, Metz surveyed the library directors' degree of involvement in a number of administrative functions from internal concerns to external matters. Unlike Lee, he found that directors concentrated the greatest part of their energy on internal library matters such as staff supervision and policy formation. ${ }^{2}$ In contrast to Lee's interviews, Metz' survey results indicated that nearly half of the directors' "contact time" was spent with members of their own staff. On the basis of such data, Metz suggested that "the degree of external involvement described by Lee's respondents may still be more a prescription of what might be desired than a description of reality.",3 
Metz asked respondents to indicate their degree of involvement in a number of administrative functions arranged in a continuum from exclusively internal to exclusively external. However, Metz separated closely related functions into external and internal categories; for instance, he considered "making up the library budget" as the number one internal function, separating it from "obtaining financial resources for the library," which he ranked as the number one external function. As Metz himself acknowledged, budgetary matters entail considerable negotiations with academic administrators and others on campus and cannot be considered a purely internal activity. With the exception of "supervising and motivating staff performance," most of the other seven functions he analyzed lacked a clear-cut distinction between internal and external focus.

Reinvestigation of the internal/external orientation of academic library directors is called for on several grounds. First, there is a growing recognition of the importance of the external involvement of library managers, yet little research has been done since Lee's and Metz' works were published. Second, conditions in colleges and universities, as well as in academic libraries, have changed considerably since the 1970s, when these studies were prepared. Third, the disparity between Lee's and Metz' conclusions regarding the external involvement of academic library directors has not been resolved.

The model of "managerial roles" developed by Henry Mintzberg offers an alternative approach to the study of library directors' internal and external involvement; the model, discussed below, provides the framework for this investigation.

\section{THE MINTZBERG MODEL OF MANAGERIAL ROLES}

Henry Mintzberg is a professor of management at McGill University and author of numerous books and articles on contemporary management issues. His initial research on managerial roles was conducted in the late 1960 s at the Sloan School of Management at the Massachu- setts Institute of Technology. He collected data on the daily activities of a number of chief executives in profit and nonprofit institutions by directly observing them at work over a given period of time. Based on these field studies, he identified ten managerial roles that he observed all managers perform. Mintzberg described these ten roles in his first book, The Nature of Managerial Work. ${ }^{4}$ In the Structuring of Organizations, ${ }^{5}$ Mintzberg distinguished between those roles that insure that the organization will operate smoothly as a single unit and those roles that involve the organization's "boundary conditions," its relationship to its environment.

Mintzberg identified the following set of roles with managing the organization's external environment:

1. Figurehead-carrying out ceremonial duties, such as greeting important outsiders

2. Liaison-developing high-level contacts for the organization and building an external information network

3. Monitor-cultivating contacts for information and serving as the contact point for those who wish to influence the organization's goals

4. Spokesperson-informing influential people in the environment about the organization's activities

5. Negotiator-working to reach agreement with outside organizations.

Mintzberg associated the following roles with staff supervision and the internal operation of the organization:

1. Leader-involving the staffing of the organization and the motivating, evaluating, and rewarding of personnel

2 . Disseminator-involving the transmission of information to employees

3. Disturbance Handler-involving the resolution of conflicts, exceptions, and disturbances sent up for resolution

4. Resource Allocator-including the design of the structure itself, the assignment of people and resources to tasks, the issuing of work orders, and the authorization of major decisions made by the employees

Mintzberg identified a third set of duties related to the organization's strategy. This included a tenth managerial role, that of 
"Entrepreneur," defined as "searching for problems and opportunities within the system and initiating projects to deal with them."

The Mintzberg model of managerial roles and his analysis of executive work characteristics have been applied to studies of administrative behavior in a number of different professions, from high school principals to police chief executives. ${ }^{6}$

\section{APPLICATION OF THE MINTZBERG MODEL}

This investigation used the Mintzberg model to analyze the different managerial roles academic library directors perform within their organizations. These roles were rephrased in terms relevant to the practicing library director. The external roles of the academic library director were defined as follows:

1. Figurehead-carrying out duties of a ceremonial nature, such as presenting and explaining the library to others

2. Liaison-maintaining contacts outside the library with college administrators and faculty

3. Monitor-receiving information outside the library through professional associations and activities and through verbal communication with colleagues

4. Spokesperson-distributing information to people outside the library and informing outsiders of progress within the system

5. Negotiator-negotiating with organizations or individuals outside the library to secure funding and safeguard interests

The managerial roles involved with the internal operation of the library were defined as follows:

1. Leader-supervising subordinates' work, including placement, training, motivation, and evaluation of employees

2. Disseminator-sharing and distributing information within the library through staff meetings and personal contacts

3. Entrepreneur-introducing change within the library by developing and implementing new systems and programs (for the purpose of this study, this was considered an internal role)

4. Disturbance Handler-handling con- flicts and crises within the library and taking corrective actions when unexpected disturbances occur

5. Resource Allocator-allocating funds, time, staff, materials, and equipment to specific tasks within the library.

\section{METHODOLOGY}

The survey method enabled this study to draw conclusions applicable to a larger population than would have been possible through interviews or direct observation.

Part 1 of the questionnaire was based on the above application of the Mintzberg model. Respondents were asked to rank their actual involvement with each of these ten roles on a five-point Likert scale. Choices included (1) least time and effort; (2) little time and effort; (3) moderate time and effort; (4) much time and effort; and (5) most time and effort.

Part 2 of the survey was designed to indicate the individuals with whom the director interacts in carrying out these managerial roles. Respondents were asked to write the percentage of their work-related contact with various groups, from academic administrators and faculty to their library staffs and professional colleagues at other institutions. This provided an alternative measure of administrative behavior with respect to internal and external role orientation.

Part 3 of the survey addressed a number of factors relating to the individual directors and their respective institutions. Individual factors included the director's sex, age, education, length of time in present position, and the last position held before the present one. Directors were also asked to indicate if they had taken any management courses over the past five years, if so, the titles of these courses. Institutional variables included the type and sponsorship of the academic institution in which the director worked, size of the professional library staff, and whether or not there was an assistant library director on the staff.

The population chosen for the study included library directors from 126 colleges and universities throughout New England. Large university libraries, such as 
Yale and University of New Hampshire, as well as small college libraries, like Regis and Marlboro, were represented in the sample. The names of institutions and library directors were identified using The HEP 1984 Higher Education Directory of American colleges and universities. The 1984 American Library Directory was used to verify names and addresses and to provide information on the size of each library's professional staff.

\section{DATA ANALYSIS: DEMOGRAPHIC DATA \\ Comparison of Respondents to Nonrespondents}

Table 1 compares demographic data for respondents and nonrespondents. The response rate by state ranged from 93.2 percent to 62.5 percent. In analyzing the data and interpreting results, it is important to have in mind an accurate picture of the responding academic institutions and their library directors. As summarized in table 2, the majority of the responding institutions were colleges (71.1 percent) and the minority (28.9 percent), universities. Seventythree percent of these were private institutions and 26.8 percent public, with more than 60 percent of the respondents representing private colleges. The size of the professional library staffs ranged from 1 to 179; 37 libraries had fewer than 5 professionals on their staffs and only 5 had more than 35 . Of the 97 responding libraries, almost half (47.4 percent) had an assistant library director on the staff.

Of the 97 directors, 93.8 percent had the
M.L.S. degree, 39.2 percent had an additional master's, and 19.6 percent had a doctorate. Of the 38 directors with a master's, 18 degrees were received in English and the humanities, 8 in social sciences, 6 in management and administration. Of the 19 directors with a doctorate, 4 degrees were in English and humanities, 3 in social sciences, and 3 in library science or administration. Almost 30 percent of the directors indicated that they had taken a management course, workshop, or institute over the past five years.

The directors' tenure (period of time in current position) ranged from a few months to 32 years. Ten percent were in office for less than 1 year and 7.2 percent for 22 years or more. Of the 97 directors responding to the survey, 24.7 percent were promoted from within their institutions and 73.2 percent were hired from outside. Twenty-four percent of the directors had previously been an assistant or associate director in an academic institution, and 14.4 percent had been library director at another institution prior to assuming their current position.

\section{ANALYSIS OF SURVEY RESPONSE External and Internal Roles}

As illustrated in tables 3 and 4, there was a significant difference in the directors' perception of the time and effort they spent on the internal and external managerial roles presented by this survey. The chi square test demonstrated a statistically significant difference between the total amount of time and effort participants re-

TABLE 1

DATA ANALYSIS: DEMOGRAPHIC DATA

\begin{tabular}{|c|c|c|c|c|}
\hline \multicolumn{5}{|c|}{ Comparison of Respondents to Nonrespondents } \\
\hline & Response & Non-Response & Total & $\begin{array}{c}\text { Percent Response } \\
\text { to Total }\end{array}$ \\
\hline \multicolumn{5}{|c|}{ Analysis by Type of Institution } \\
\hline $\begin{array}{l}\text { Type } \\
\text { College } \\
\text { University } \\
\text { Total }\end{array}$ & $\begin{array}{l}69 \\
28 \\
97\end{array}$ & $\begin{array}{r}20 \\
9 \\
29\end{array}$ & $\begin{array}{r}89 \\
37 \\
126\end{array}$ & $\begin{array}{l}77.5 \\
75.6 \\
77\end{array}$ \\
\hline \multicolumn{5}{|c|}{ Analysis by Institutional Sponsorship } \\
\hline $\begin{array}{l}\text { Sponsorship } \\
\text { Public } \\
\text { Private } \\
\text { Total }\end{array}$ & $\begin{array}{l}26 \\
71 \\
97\end{array}$ & $\begin{array}{r}3 \\
26 \\
29\end{array}$ & $\begin{array}{r}29 \\
97 \\
126\end{array}$ & $\begin{array}{l}89.7 \\
73.2 \\
77\end{array}$ \\
\hline
\end{tabular}


TABLE 2

DATA ANALYSIS: DEMOGRAPHIC DATA

\begin{tabular}{|c|c|c|}
\hline \multicolumn{3}{|c|}{ Description of Respondents } \\
\hline Institutional Type & Number & Percent \\
\hline \multicolumn{3}{|c|}{ Institutional Variables } \\
\hline & 69 & \\
\hline University & 28 & 28.9 \\
\hline Total & 97 & \\
\hline \multicolumn{3}{|c|}{ Institutional Sponsorship } \\
\hline Public & 26 & \\
\hline Private & 71 & 73.2 \\
\hline Total & 97 & 100 \\
\hline \multicolumn{3}{|c|}{ Size of Professional Staff } \\
\hline$<5$ & 37 & 38.1 \\
\hline $5-14$ & 39 & 40.2 \\
\hline $15-24$ & 11 & 11.3 \\
\hline $25-34$ & 5 & 5.2 \\
\hline $35>$ & 5 & 5.2 \\
\hline Total & 97 & 100 \\
\hline \multicolumn{3}{|c|}{ Assistant Library Director } \\
\hline Yes & 46 & 47.4 \\
\hline No & 51 & 52.6 \\
\hline Total & 97 & 100 \\
\hline \multicolumn{3}{|l|}{ Director Variables } \\
\hline & & \\
\hline Male & 49 & 50.5 \\
\hline Female & 48 & 49.5 \\
\hline Total & 97 & 100 \\
\hline \multicolumn{3}{|l|}{ Age } \\
\hline 20-29 Years & 3 & 3.1 \\
\hline $30-39$ Years & 16 & 16.5 \\
\hline 40-49 Years & 29 & 29.9 \\
\hline 50-59 Years & 34 & 35.1 \\
\hline Over 60 & 13 & 13.4 \\
\hline No Response & 2 & 2.1 \\
\hline Total & 97 & 100 \\
\hline \multicolumn{3}{|l|}{ Tenure } \\
\hline$<1$ Year & 10 & 10.3 \\
\hline 1-3 Years & 15 & 15.5 \\
\hline 4-6 Years & 17 & 17.5 \\
\hline 7-9 Years & 10 & 10.3 \\
\hline $10-12$ Years & 11 & 11.3 \\
\hline 13-15 Years & 10 & 10.5 \\
\hline 16-18 Years & 10 & 10.3 \\
\hline 19-21 Years & 7 & 7.2 \\
\hline$>22$ Years & 7 & 7.2 \\
\hline Total & 97 & 100 \\
\hline
\end{tabular}

ported spending on external and internal roles. The chi-square value of 66.24 (4 degrees of freedom at a $P$ value of .05) was well beyond what would be expected by chance. These differences were further analyzed by examining the percentages for the combined total of all 5 external roles compared to the combined total of all 5 internal roles. Based on the summary data in table 4 , table 5 shows that of the 485 responses to the combined external roles, 64 (13.2 percent) indicated "least" time and effort was expended on external roles, compared to 21 directors ( 4.3 percent) for "least" time and effort spent on internal roles. One hundred and seventeen directors ( 24.1 percent) spent "little" time and effort on external roles, compared to 82 (16.9 percent) who spent "little" on internal roles. Almost the opposite was true for the other side of the Likert scale. Only 18 directors (3.7 percent) indicated "most" time and effort was devoted to the 5 external roles, but 59 (12.2 percent) responded that "most" time and effort was devoted to the 5 internal roles. Eighty-five directors (17.5 percent) spent "much" time on the external roles compared to 144 (29.7 percent) who spent "much" time on internal roles. About 5 percent more of the respondents spent "moderate" time and effort on the combined external roles than the combined internal ones.

When the two sides of the Likert scale were compared ("least/little" versus "much/most"), the results were even more dramatic. One hundred and three directors (21.2 percent) spent "much/ most" of their time on external roles compared to 203 directors ( 41.9 percent) who spent "'much/most" time on internal roles. Conversely, the percentage indicating "least/little" time on external roles (37.3 percent) was almost double the percentage spending "least/little" time on internal roles (21.2 percent).

\section{Work-Contact Time}

In Part 2 of the questionnaire, directors were asked to indicate the percentage of work-contact time they spent with others. These percentages corroborate the findings in Part 1 of the survey, suggesting respondents' overall internal orientation. Seventy-five of the directors indicated that they spent less than 10 percent of their time with the administrator to whom they report, and 60 directors spent less than 10 percent of their time with other administrators at their institutions. Directors appeared to spend more time with faculty than with administrators.

Forty-seven percent of the directors 
TABLE 3

ANALYSIS OF SURVEY RESPONSE

SUMMARY OF EXTERNAL AND INTERNAL ROLES

\begin{tabular}{|c|c|c|c|c|c|c|}
\hline \multicolumn{7}{|c|}{ Time and Effort (Frequency) } \\
\hline Role & $\begin{array}{l}\text { Least } \\
\text { (1) }\end{array}$ & $\begin{array}{c}\text { Little } \\
\text { (2) }\end{array}$ & $\begin{array}{l}\text { Moderate } \\
\text { (3) }\end{array}$ & $\begin{array}{c}\text { Much } \\
\text { (4) }\end{array}$ & $\begin{array}{c}\text { Most } \\
\text { (5) }\end{array}$ & Total \\
\hline \multicolumn{7}{|l|}{ External } \\
\hline Figurehead & 34 & 32 & 27 & 4 & 0 & 97 \\
\hline Liaison & 1 & 6 & 46 & 38 & 6 & 97 \\
\hline Monitor & 9 & 27 & 49 & 9 & 3 & 97 \\
\hline Spokesperson & 6 & 25 & 45 & 18 & 3 & 97 \\
\hline Negotiator & 14 & 27 & 34 & 16 & 6 & 97 \\
\hline Total & 64 & 117 & 201 & 85 & 18 & 485 \\
\hline \multicolumn{7}{|l|}{ Internal } \\
\hline Leader & 2 & 23 & 46 & 19 & 7 & 97 \\
\hline Disseminator & & 8 & 38 & 38 & 11 & 97 \\
\hline Entrepreneur & 3 & 7 & 28 & 39 & 20 & 97 \\
\hline Disturbance Handler & 12 & & 36 & 17 & 5 & 97 \\
\hline Resource Allocator & 2 & 17 & 31 & 31 & 16 & 97 \\
\hline Total & 21 & 82 & 179 & 144 & 59 & 485 \\
\hline
\end{tabular}

TABLE 4

Summary of External and Internal Roles: Time and Effort

Chi Square

\begin{tabular}{lllllll}
\hline \hline Role & $\begin{array}{l}\text { Least } \\
(1)\end{array}$ & $\begin{array}{c}\text { Little } \\
(2)\end{array}$ & $\begin{array}{c}\text { Moderate } \\
(3)\end{array}$ & $\begin{array}{c}\text { Much } \\
(4)\end{array}$ & $\begin{array}{c}\text { Most } \\
(5)\end{array}$ & Total \\
\hline External & 64 & 117 & 201 & 85 & 18 & 485 \\
& $(42.5)$ & $(99.5)$ & $(190)$ & $(114.5)$ & $(38.5)$ & 485 \\
Internal & 21 & 82 & 179 & 144 & 59 & 48.5 \\
& $(42.5)$ & $(99.5)$ & $(190)$ & $(114.5)$ & $(38.5)$ & 970 \\
Total & 81 & 199 & 380 & 229 & 77 & \\
\hline
\end{tabular}

Total Chi Square $=10.88+3.08+.64+7.60+10.92$

$10.88+3.08+.64+7.60+10.92=66.24$

Degrees of Freedom $=4$

PValue $=<.05$ (statistically significant)

Expected frequencies are in parentheses

TABLE 5

Summary of External and Internal Roles: Time and Effort Percentages

\begin{tabular}{lcccccc}
\hline \hline Role & $\begin{array}{c}\text { Least } \\
(1)\end{array}$ & $\begin{array}{c}\text { Little } \\
(2)\end{array}$ & $\begin{array}{c}\text { Moderate } \\
(3)\end{array}$ & $\begin{array}{c}\text { Much } \\
(4)\end{array}$ & $\begin{array}{c}\text { Most } \\
(5)\end{array}$ & Total \\
\hline External & 13.2 & 24.1 & 41.4 & 17.5 & 3.7 & 100 \\
Internal & 4.3 & 16.9 & 36.9 & 29.7 & 12.2 & 100 \\
\hline
\end{tabular}

spent more than 50 percent of their time with their staff, including 9 who spent 70 percent or more of their work-contact time with staff. Only 7 directors spent less than 20 percent of their time with staff, and of these, only 1 director spent less than 10 percent of his time with his staff. Directors appeared to spend more time with students than might be expected, perhaps because they included student library assistants in this category. Twenty-nine directors spent 10 to 30 percent of their work-contact time with students, 9 spent more than 30 percent of their time, and 56 spent less than 10 percent.

The questionnaire provided respondents with the opportunity to indicate other work-contact time. Almost 30 percent of the respondents reported spending more than 20 percent of their time working alone. Responses varied from "planning time," "solo time," and "li- 
brary duties," to "professional reading," "research," and "publishing." Thirteen directors indicated that they spent various amounts of work-contact time with "funding agencies," "friends of the library" and "donors"; 7 specified network and consortium contacts, and 2 mentioned vendors and sales representatives.

\section{CONCLUSIONS}

The academic library directors who participated in this study were clearly more involved with internal managerial roles and work contacts than with external ones. These findings corroborate Metz' 1977 survey of academic library directors, who reported that their work contacts and administrative functions were more internal than external in orientation. Metz concluded that directors at larger, more complex institutions were more heavily involved with external issues and that personal variables, like sex, age, and education, had little influence on administrative roles.?

In interpreting the results of the present study, it is important to recognize that more than 60 percent of the respondents were library directors from private colleges and that almost 40 percent of the directors had fewer than five professional librarians on their staffs. Although size of professional staff did not make a significant difference in the time and effort directors spent on the ten managerial roles, a chi-square analysis indicated that university library directors were considerably more involved in two of the external roles (liaison and monitor) than their college counterparts, and directors from public institutions were more active in the internal role of disturbance handler than their colleagues at private institutions. Had more directors from universities and public institutions been included in the population studied, other significant relationships between managerial role and institutional size and sponsorship might have been observed.

Over the past decade much has been written on the manager's need to cultivate and maintain external organizational con- tacts and commitments. In their commentary on successful American companies, Peters and Waterman asserted that "in general the excellent company values almost always stress being close to the customer or are otherwise externally focused. ${ }^{1 / 8}$ According to a recent article in Chronicle of Higher Education, presidents of colleges and universities see a marked shift in their roles from internal to external focus "from the old-style president in residence almost all the time to a modern mixture of presidential demands on and off campus." In describing their responsibilities, presidents stated that they must be both an internal and external president to be effective and that they felt much greater external political pressure and intrusion.

Unlike business executives and college administrators, academic library directors are not the chief administrative officers in their institutions. However, like other managers, they have important political and practical roles to play outside their respective organizations and, to do so, must delegate many internal operations to subordinates. Although almost half of the respondents had an assistant library director, the directors were primarily involved with the internal operations of their libraries. Considering the importance of the negotiator role in securing budgetary support and safeguarding library interests, it was particularily surprising to find only 23 percent of the directors spent "much/ most" time and effort on this external role whereas 42 percent spent the "least/little" time.

Mintzberg recognized that there was more to managing an organization than direct supervision of staff. He urged managers to be attentive to their organization's relationship to its external environment. This study suggests that academic library directors need to be more attuned to their roles as spokesperson in informing influential people about the library, liaison in developing high-level contacts for the library, monitor in using these contacts for information, negotiator in reaching major agreements with outside parties, and figurehead in representing the library to others on campus. 


\section{REFERENCES AND NOTES}

1. Susan Lee, "Conflict and Ambiguity in the Role of the Academic Library Director," College and Research Libraries 38:396-403 (Sept. 1977).

2. Paul Metz, "The Academic Library and Its Director in Their Institutional Environments" (Ph.D. diss., Univ. of Michigan, 1977).

3. Paul Metz, "The Role of the Academic Library Director," Journal of Academic Librarianship 5:149 July 1979).

4. Henry Mintzberg, The Nature of Managerial Work (New York: Harper, 1973).

5. Henry Mintzberg, The Structuring of Organizations: A Synthesis of Research (Englewood Cliffs, N.J.: Prentice-Hall, 1979), p.25-26.

6. Danny Earl Bloom, "A Replication of Martin's Test of Mintzberg's Six Managerial Characteristics" (Ed.D. diss., Univ. of Kansas, 1983); Martha Larsen Hale, "A Structured Observation Study of the Nature of City Managers' Work" (Ph.D. diss., Univ. of Southern California, 1983); William Martin and Donald Willower, "The Managerial Behavior of High School Principals," Educational Administrative Quarterly 17 (Winter 1981); Louis Allen Mayo, "Analysis of the Role of the Police Chief Executives" (Ph.D. diss., American Univ., 1983).

7. Paul Metz, "The Role of the Academic Library Director," p.151.

8. Thomas J. Peters and Robert H. Waterman, Jr., In Search of Excellence: Lessons from America's Best-Run Companies (New York: Harper, 1982), p.77.

9. Jean Evangelauf, "Presidents Say They're Spending More Time Away from Campuses," Chronicle of Higher Education 29:1,15 (Nov. 21, 1984). 